\title{
Species diversity of the old genus Navicula Bory (Bacillariophyta) on intertidal sand-flats in the Nakdong River estuary, Korea
}

\author{
Gyeongje Joh* \\ Department of Environmental Science and Engineering, Inje University, Gimhae 621-749, Korea
}

\begin{abstract}
Remarkable diversity of diatom taxa occurs in intertidal sand-flats of the Nakdong River estuary, one of the most dynamic and productive ecosystem in Korea. Benthic diatoms were collected from the sandy sediments to clarify the taxonomic accounts and distribution of the old genus Navicula, i.e., the naviculoid flora. Total 92 taxa belonging to Navicula sensu stricto and 22 genera separated from Navicula sensu lato are reported with brief descriptions and micrographs, and many species remain unidentified. The genera are ranked by the number of diatom species: Navicula of 33 species and varieties, Fallacia of 17 species, Placoneis of five species, Fogedia and Parlibellus of four species, Austariella, Hippodonta and Petroneis of three species, Cosmioneis, Diadesmis, Luticola, Moreneis and Sellaphora of two species and variety, Berkeleya, Chamaepinnularia, Cocconeiopsis, Diademoides, Dickieia, Eolimna, Geissleria, Haslea, Lyrella and Mayamaea of one species. Through 32 samplings of the 12 areas, the important species were identified Navicula perminuta, N. gregaria, N. torneensis, Fallacia cunoniae, F. litoricola, F. subforcipata, F. tenera. The naviculoid diatoms constitute an average of $27 \%$ (range: minimum to maximum, 5-75\%), of the benthic diatom assemblages. The diatom assemblages are characterized by the colonizing of a few dominant or frequent species and many occasional or rare species. The dominant species were observed to fluctuate with sampling site and time. Among the reported naviculoid diatoms, 46 taxa are newly reported in Korea.
\end{abstract}

Key words: benthic diatoms, intertidal sand-flats, naviculoid species, the Nakdong River estuary

\section{INTRODUCTION}

Many non-planktonic diatoms occur in estuarine and coastal areas, and they are usually confined to intertidal zones. They also live in a variety of substrates, including plants and macroalgae (epiphyton), stones and rocks (epilithon), and sediment or other non-living surfaces (periphyton) (Round 1971). Diatoms associated with sediments are further subdivided into those that attach to sand grains (epipsammon) and those that colonize the surface of the silty sediment (epipelon). Intertidal mudand sand-flats or salt marshes along the coast and estuaries are especially suitable habitats for diatoms associated with sediments, because sufficient nutrient and irradiance are available. As epibenthic assemblages of diatoms exhibit great species diversity in the intertidal areas, many sudies have shown the presence of diverse diatom taxa in the intertidal zones, in Beaufort, North Carolina (Hustedt 1955); Göteborg on the west coast of Sweden (Aleem 1973); Yaquina Estuary, Oregon; and Scripps Beach, California (Amspocker 1977a, 1977b), in Northeast Asia (Park et al. 2012), in tropical area (Mitbavkar and Anil 2002), and even in Antarctica (Al-Handal and Wulff 2008).

Intertidal sediments along coast and estuary are the http://dx.doi.org/10.5141/ecoenv.2013.371

(c) $\begin{aligned} & \text { This is an Open Access article distributed under the terms of } \\ & \text { the Creative Commons Attribution Non-Commercial Licens } \\ & \text { (http://creativecommons.org/licenses/by-nc/3.0/) which }\end{aligned}$
permits unrestricted non-commercial use, distribution, and reproduction in any
medium, provided the original work is properly cited.
Received 29 October 2013, Accepted 22 November 2013

*Corresponding Author

E-mail: kjcho@inje.ac.kr Tel: +82-55-320-3216 


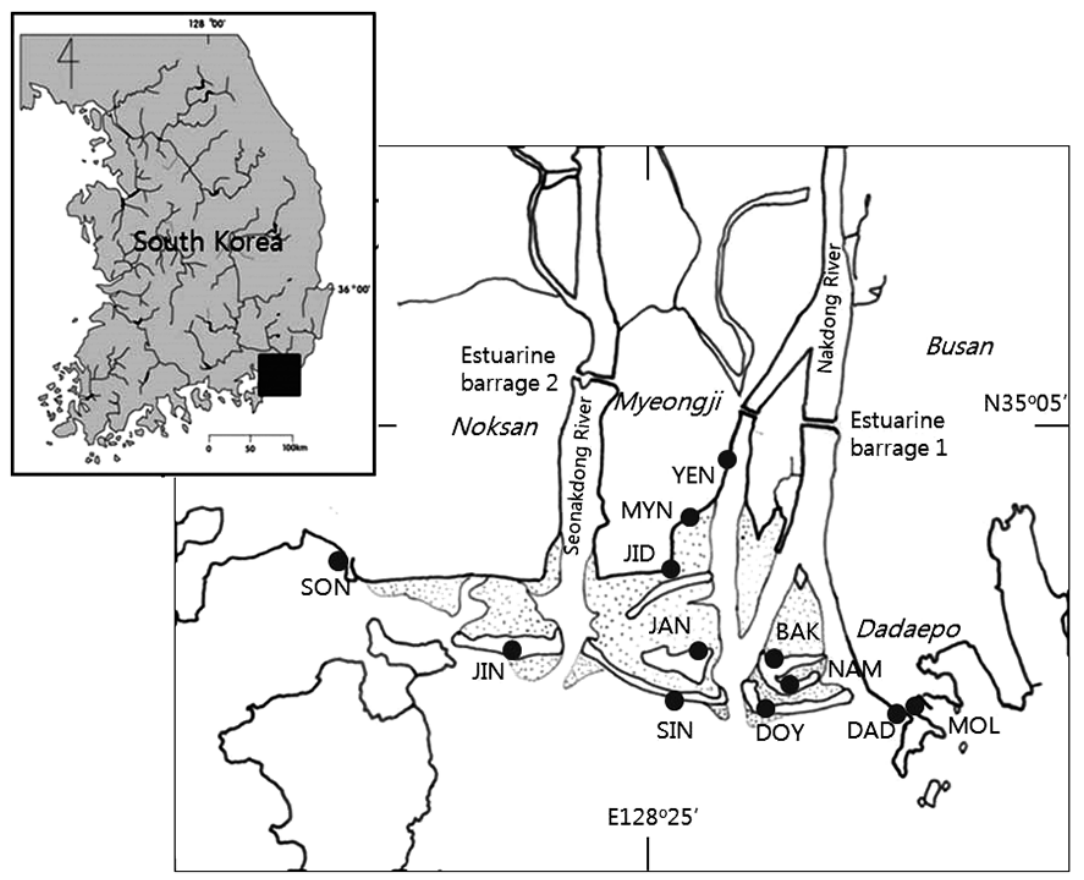

Fig. 1. Map showing the estuary of two rivers and the coastal area of the sea. Sampling sites on the intertidal sandflats consisted of six sand bars: JIN (Jinudo), SIN (Sinjado), JAN (Jangjado), DOY (Doyodeung), NAM (Namuseomdeung), BAK (Baekhapdeung), and six beaches: DAD (Dadaepo), MOL (Molundae), YEN (the estuary of the Yeong Stream), MYN (Myeongji), JID (Jindong), SON (Songjeong). Dotted areas between sand bars indicate the sand-flats.

most productive in aquatic and terrestrial ecosystem (Odum 1956), and the algal production in this area contributes significantly to the energy flow of the ecosystem (Pomeroy 1959). Benthic algae have been recognized as important primary producers and play an important role in the ecology of marine littoral regions. Intertidal sediments in coasts are rich in flora and high in abundance of taxa belonging to the biraphid diatoms, particularly Navicula sensu lato (Hustedt and Aleem 1951, Amspocker and McIntire 1978, Mitbavkar and Anil 2002, Hauboisa et al. 2005). The Nakdong River estuary is reported to be the most productive in Korean ecosystems by Korean ecologists, in the research supported by the International Biological Program (IBP) (Kim et al. 1972, Kim et al. 1982).

Microalgal studies in this estuarine area, to date, have been on the plankton or tychoplankton species, while benthic diatoms have been scarcely studied or ignored. The diatom flora in this area has already been shown in the doctoral thesis of Cho (1988). However, the data have not yet been published in journal articles, because a number of the reported taxa remain unidentified. The biomass and diversity index of benthic algae are recently reported by Du et al. (2009), and some species compositions of the genera Amphora and Navicula are shown.

The current study aims to contribute to the taxonomic clarification of the Navicula diatom flora occurring in intertidal sand-flats. In addition to the detailed morphological presentations, the nomenclature and taxonomic status of the benthic diatoms are to be presented. Temporal and spatial distributions of benthic diatoms in sand flats were investigated. Such a study will provide insights into the ecological characteristics and dynamics of microbenthic assemblages in intertidal areas.

\section{MATERIALS AND METHODS}

\section{Sampling sites}

In the mouth of the Nakdong River, tidal flats extend up to $10 \mathrm{~km}$ from the coastal sea-line and $3.8 \mathrm{~km}$ in width (Fig. 1). A plain, with nearly no altitude, no inclination, and ca. $40 \mathrm{~km}^{2}$ of surface area $\left(35^{\circ} 04^{\prime}-35^{\circ} 08^{\prime} \mathrm{N}\right.$, $128^{\circ} 85^{\prime}-128^{\circ} 96^{\prime} \mathrm{E}$ ), is formed below the estuarine barrage. An estuarine barrage was constructed in 1987 to prevent the intrusion of sea water and to secure a water resource for agricultural irrigation, industrial use, and drinking water. Six bars, each of which is an elongated ridge of sand, are lined along the coastline. Sand bars, tidal flats between sand bars, and beaches at the marginal area of the 
coast are associated as well in the area. But the sand bars have been influenced by the erosion and sedimentation by current and flows, and they are not stable. Topography along coastline changes frequently in spatial and temporal scales. Tidal flats are outspread between the sand bars and are partially covered with halophyte vegetation. The estuarine area that is visited by migratory birds is designated as a natural monument and a protection area by the government. This area is a microtidal estuary with the maximum tidal amplitude of $2 \mathrm{~m}$ during the spring tide.

Sampling sites can be divided into two areas, sand bars off the shore and beaches along the shore. Particularly, the YEN site is in the estuary of a stream and is under the strong influence of freshwater, while the DAD and MOL site under the sea water. The 32 samples have been collected from the six zones, JIN, SIN, DOY, JAN, NAM and BAK, at sand bars, and six areas, MOL, DAD, YEN, MYN, JID and SON, at the beach (Fig. 1). The diatom materials have been collected for a long times, in 1986, 1991, 2007 and 2013.

\section{Specimen preparations}

The sands or sediments were collected at a depth of $0.5 \mathrm{~cm}$ from the surface by using a cylinder $(3.0 \mathrm{~cm}$ in diameter). The size of the sediment grain in the sand bars ranged from $0.16 \mathrm{~mm}$ to $0.27 \mathrm{~mm}$ (mean $0.18-0.23 \mathrm{~mm}$ ) (Kim et al. 2007). The sand materials were oxidized using nitric acid and potassium dichromate in a sand bath, followed by repeated washing with distilled water. Diatoms were observed under oil immersion by using two types of light microscopes, including an Olympus Provis AX2 microscope (Olympus, Tokyo, Japan), equipped with differential interference contrast (DIC) optics and an Axioplan microscope (Carl Zeiss, Oberkochen, Germany). Diatom frustules were counted from 300 to 350 for each sample, and the frequency and relative abundance of each species were determined.

Some specimens were observed under a scanning electron microscope (SEM) to clarify the identification. The cleaned diatom frustules were dried on small coverslips, which were attached to aluminum stubs and coated with a deionized gold spray. SEM observations were made using the Hitachi S-4200 SEM (Hitachi, Tokyo, Japan). Various literatures were used as references for diatom identification. Taxonomic authorities referred were as follows: Hustedt (1961-1966), Krammer and Lange-Bertalot (1986), Sabbe et al. (1999), Witkowski et al. (2000), LangeBertalot (2001), Park et al. (2012) and other literatures.

\section{RESULTS}

The 92 diatom taxa belonging to the old genus $\mathrm{Na}$ vicula were observed in the intertidal sand-flats of the Nakdong River estuary. They include the genus Navicula sensu stricto and the revised genera separated from the genus Navicula sensu lato. The frustule dimensions, occurrence frequency, and relative abundance of each taxon are given in the description of each species. The abundance of each taxon was presented as the dominance percentage of the naviculoid diatoms. Occurrece frequency of species among the naviculoid diatoms was divided into five ranks, including common (>18 occurrences in 32 sediment samples), frequent (10-17 occurrences), occasional (5-9), rare (3-4) and very rare (1-2). The taxonomic authorities of the taxa were added to the descriptions as well. The cellular dimensions are provided for local specimens, and the length (L) and breadth (B) of the valves and the stria numbers (S) in $10 \mu \mathrm{m}$ in the middle parts of the valve are shown. Additionally, the stria numbers in middle and in ends of the valve are divided using a tilde mark ( ). The taxa are arranged in alphabetical order, but the photographic plates are arranged according to morphological affinity. Most SEM observations were made at x2000 magnification. On the diatom list (see below), the newly recorded 46 taxa in Korea are marked with an asterisk $\left(^{*}\right)$ in the front of each scientific name.

\section{Austariella Witkowski, Lange-Bertalot \& Metzel- tin 2000}

1. *Austariella admissa (Hustedt) Witkowski, LangeBertalot \& Metzeltin 2000 (Pl. 4, Fig. 21) (Witkowski et al. 2000, p 154, pl. 66: 5-9). Basionym: Navicula admissa Hustedt 1955. L: $15-17 \mu \mathrm{m}$; B: $9 \mu \mathrm{m}$; S: 12-14/10. Rare, occurring only on the MOL beach. Newly reported in Korea.

2. *Austariella jamalinensis (Cleve in Cleve and Grunow) Witkowski, Lange-Bertalot \& Metzeltin 2000 (Pl. 4, Fig. 22) (Witkowski et al. 2000, p 155, pl. 66: 1-3, 10-12). Basionym: Navicula jamalinensis Cleve in Cleve and Grunow 1880. L: 9-23 $\mu \mathrm{m}$; B: 5-9.5 $\mu \mathrm{m}$; S: 12-13/10. Rare, occurrimg in two samples from the MOL beach and SON sand flat. Newly reported species in Korea.

3. Austariella sp. 69 (Pl. 4, Fig. 23). This species is similar to A. jamalinensis except irregular rows of puncta on the axial area of the valve. Rare, occurring only on the southern slope of the DOY sand bar. 


\section{Berkeleya Greville 1827}

4. Berkeleya scopulorum (Brébisson) Cox 1979 (Pl. 4, Figs. 24, 25). Basionym: Navicula scopulorum Brébisson in Kützing 1849 (Hustedt 1961-1966, p 25, fig.

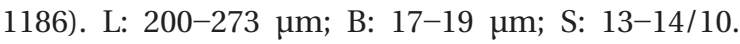
Rare, occurring on only one sample from the SON sand-flat

\section{Chamaepinnularia Lange-Bertalot \& Krammer in Lange-Bertalot and Metzeltin 1996}

5. *Chamaepinnularia clamans (Hustedt) Witkowski, Lange-Bertalot \& Metzeltin 2000 (Pl. 6, Fig. 14) (Witkowski et al. 2000, p 169, pl. 69: 12). Basionym: Navicula clamans Hustedt 1939. L: $15 \mu \mathrm{m}$; B: $6 \mu \mathrm{m}$; S: $18 / 10$. Very rare in only one sample from the SON sandflat. Newly reported in Korea.

\section{Cocconeiopsis Witkowski, Lange-Bertalot \& Met- zeltin 2000}

6. *Cocconeiopsis kantsinensis (Giffen) Witkowski, Lange-Bertalot \& Metzeltin 2000 (Pl. 4, Fig. 27) (Witkowski et al. 2000, p 173, pl. 67: 3-7, 68: 2, 3). Basionym: Navicula kantsinensis Giffen 1967. L: 18-30

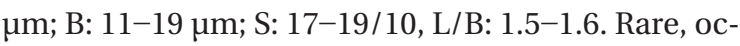
curring on the DOY sand bar, and the DAD and MOL beaches with low abundance. Newly reported species in Korea.

\section{Cosmioneis Mann \& Stickle in Round et al. 1990}

7. ${ }^{*}$ Cosmioneis eta (Cleve) Witkowski, Lange-Bertalot \& Metzeltin 2000 (Pl. 5, Fig. 8; Pl. 6, Fig. 1) (Witkowski et al. 2000, p 176, pl. 98: 7, 107: 3). Basionym: Navicula eta Cleve 1893. L: 16-35 $\mu \mathrm{m}$; B: 9-17 $\mu \mathrm{m}$; S: (14-18/10) (18-22/10). Rare, occurring in some samples from the NAM, SIN, and JAN sand bars. Newly reported in Korea.

8. ${ }^{*}$ Cosmioneis grossepunctata (Hustedt) Mann in Round et al. 1990 (Pl. 6, Fig. 5) (Witkowski et al. 2000, p 177, pl. 107: 1-11). Basionym: Navicula grossepunctata Hustedt 1944. L: $42 \mu \mathrm{m}$; B: $15 \mu \mathrm{m}$; S: 10/10. Very rare, occurring only on the northern parts of the BAK sand bar. Newly reported in Korea.

\section{Diademoides Kemp \& Paddock 1990}

9. *Diademoides luxuriosa (Greville) Kemp \& Paddock
1990 (Pl. 6, Fig. 4). Synonym: Diadema luxuriosa (Greville) Kemp \& Paddock 1989 (Kemp and Paddock 1989, p 39, figs. 1-10), Navicula luxuriosa Greville

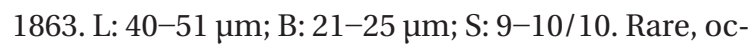
curring in three areas, the JAN sand flat, the DAD and MOL beach. Newly reported species in Korea.

\section{Diadesmis Kützing 1844}

10. Diadesmis confervacea Kützing 1844. Synonym: Navicula confervacea (Kützing) Grunow in Van Heurck 1880 (Krammer and Lange-Bertalot 1986, p 221, pl. 75: 29-31). L: $18 \mu \mathrm{m}$; B: $6.3 \mu \mathrm{m}$; S: 22/10. Freshwater diatoms, occurring rarely in the northern parts of the DOY sand bar.

11. Diadesmis contenta (Grunow ex Van Heurck) Mann in Round et al. 1990 (Pl. 4, Figs. 15, 16). Basionym: Navicula contenta Grunow in Van Heurck 1885 (Krammer and Lange-Bertalot 1986, p 219, pl. 75: 1-5). L: 8.6-10 $\mu \mathrm{m}$; B: $2.5 \mu \mathrm{m}$. Occasionally, occurring in some samples from the JAN, SIN, BAK, and SON sand-flats, and in the YEN, but with low abundance.

\section{Dickieia Berkeley ex Kützing 1844}

12. ${ }^{*}$ Dickieia ulvacea Berkeley in Kützing 1844 (Pl. 4, Figs. 3, 4) (Witkowski et al. 2000, p 181, pl. 108: 16, 17). Synonym: Navicula ulvacea (Berkeley) Cleve 1894. L: 11-18 $\mu \mathrm{m}$; B: $4.2-5.5 \mu \mathrm{m}$. Very rare, occurring on the MOL beach. Newly reported in Korea.

\section{Eolimna Lange-Bertalot \& Schiller in Schiller and Lange-Bertalot 1997}

13. Eolimna minima (Grunow in Van Heurck) LangeBertalot in Moser et al. 1998 (Pl. 4, Figs. 7-9). Basionym: Navicula minima Grunow in Van Heurck 1880 (Krammer and Lange-Bertalot 1986, p 229, pl.

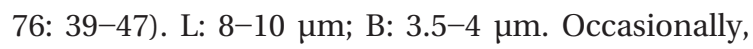
occurring in some samples from the SIN, NAM, BAK, and others, with very low abundances.

\section{Fallacia Stickle \& Mann in Round et al. 1990}

14. *Fallacia amphipleuroides (Hustedt) Mann in Round et al. 1990 (Pl. 6, Fig. 15) (Witkowski et al. 2000: 200, pl. 71: 43, 44). Basionym: Navicula amphipleuroides Hustedt 1955. L: $8.5 \mu \mathrm{m}$; B: $4.5 \mu \mathrm{m}$. Very rare, occurring only on the MOL beach. Newly reported in Korea. 

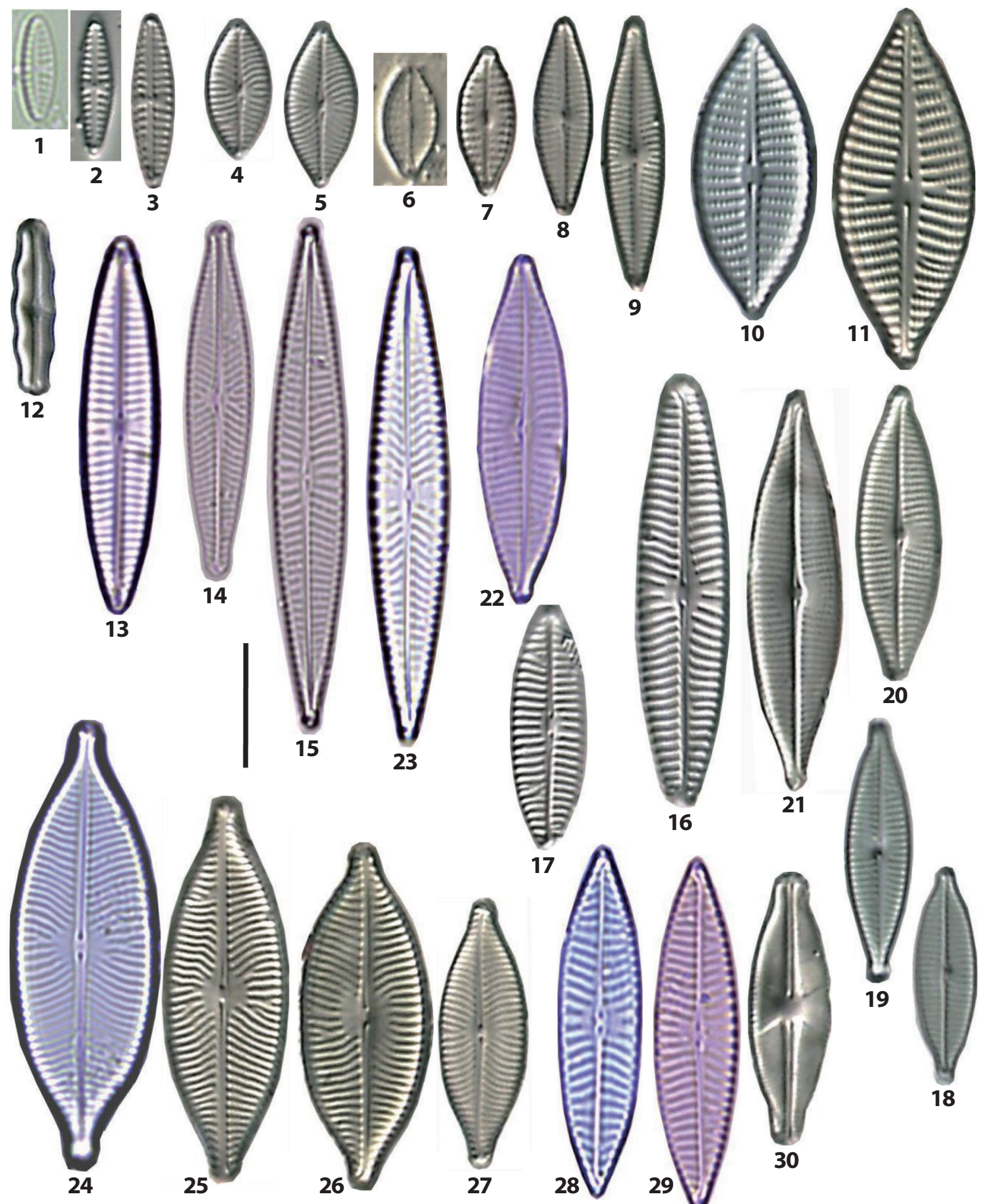

Plate 1. Figs. 1-3. Navicula perminuta. Figs. 4, 5. N. pseudosalinarioides. Figs. 6, 7. N. viminoides. Figs. 8, 9. N. veneta. Figs. 10, 11. N. perrhombus. Fig. 12. N. tridentula. Fig. 13. N. tripunctata. Fig. 14. N. cryptocephala. Fig. 15. N. agnita. Figs. 16, 17. N. recens. Figs. 18-21. N. gregaria. Fig. 22. N. germainii. Fig. 23. N. arenaria var. rostellata. Figs. 24, 25. N. salinarum. Fig. 26. N. salinarum var. rostrata. Fig. 27. N. salinarum var. minima. Fig. 28, 29. N. erifuga. Fig. 30. N. gerloffii. Scale bar, $10 \mu \mathrm{m}$. 
15. *Fallacia cryptolyra (Brockmann) Stickle \& Mann in Round et al. 1990 (Pl. 7, Figs. 1, 2) (Witkowski et al. 2000, p 203, pl. 70: 42-45). Basionym: Navicula cryptolyra Brockmann 1950. L: 8.5-15 $\mu \mathrm{m}$; B: 4-7 $\mu \mathrm{m}$; S: $22 / 10$. Rare, occurring on two beaches, the DAD and MOL. Newly reported in Korea.

16. *Fallacia cunoniae (Cholnoky) Witkowski, LangeBertalot \& Metzeltin 2000 (Pl. 7, Figs. 21, 22) (Witkowski et al. 2000, p 203, pl. 70: 37). Basionym: Navicula cunoniae Cholnoky 1963. L: 7.5-12 $\mu \mathrm{m}$; B: 4-5 $\mu \mathrm{m}$. Common, occurring on many sand bars or beaches. The orders of abundances are as follows: DAD (60\%), MOL (34\%), JAN (11\%) and DOY (9\%). Newly reported species in Korea.

17. *Fallacia dithmarsica (König in Hustedt) Round et al. 1990 (Pl. 7, Figs. 6, 7) (Witkowski et al. 2000, p 204, pl. 71: 21, 22). Basionym: Navicula dithmarsica König in

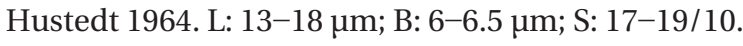
Occasionally, occurring in many samples from the JIN, DOY, BAK, DAD, and other sand flats, and their abundances are very low. Newly reported species in Korea.

18. *Fallacia florinae (Moeller) Witkowski 1993 (Pl. 7, Figs. 12-15) (Witkowski et al. 2000, p 204, pl. 71: 45-49). Basionym: Navicula florinae Moeller 1950. L: 6.5-20 $\mu \mathrm{m}$; B: 4-9 $\mu \mathrm{m}$; S: 23-24/10. One of the most common species, occurring on most sand bars and beaches, but very low in relative abundances. Newly reported species in Korea.

19. Fallacia forcipata (Greville) Stickle \& Mann in Round et al. 1990 (Pl. 6, Figs. 18-21) (Witkowski et al. 2000, p 205. pl. 72: 2-9). Basionym: Navicula forcipata Greville 1859. L: 26-34 $\mu \mathrm{m}$; B: 11-15 $\mu \mathrm{m}$; S: 16-17/10. Frequently, occurring in 11 sites from four areas, i.e., JAN, DOY, DAD and SON. The abundances are $<4 \%$.

20. *Fallacia gemmifera (Simonsen) Mann in Round et al. 1990 (Pl. 7, Figs. 25, 26). Basionym: Navicula gemmifera Simonsen 1960 (Hustedt 1961-1966, p 543, fig.

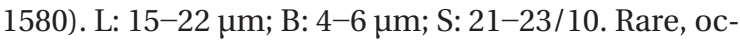
curring only on the sand flat of the YEN. Newly reported in Korea.

21. *Fallacia litoricola (Hustedt) Mann in Round et al. 1990 (Pl. 6, Figs. 6-9) (Witkowski et al. 2000, p 206, pl. 72: 31-34). Basionym: Navicula litoricola Hustedt 1955. L: 12-23 $\mu \mathrm{m}$; B: 5-8 $\mu \mathrm{m}$; S: 19-23/10. Occasionally, occurring on the DOY, BAK, DAD, and other sand-flats, the maximum abundance is $17 \%$ in the DOY and $\leq 4 \%$ in the remaining areas. Newly reported species in Korea.

22. *Fallacia nyella (Hustedt) Mann in Round et al. 1990
(Pl. 7, Fig. 16) (Witkowski et al. 2000, p 209, pl. 70: 1-7). Basionym: Navicula nyella Hustedt 1964. L:

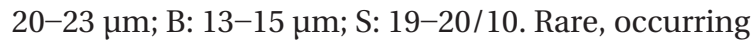
on the JAN and DOY sand bars, together with F. florinae. Newly reported species in Korea.

23. *Fallacia omissa (Hustedt) Mann 1990 (Pl. 7, Figs. 18-20) Synonym: Navicula monoculata var. omissa (Hustedt) Lange-Bertalot 1985 (Krammer and LangeBertalot 1986, p. 174, pl. 66: 17, 18). L: 10.5-21 $\mu \mathrm{m}$; B: 4.5-6.5 $\mu \mathrm{m}$; S: 20-24/10. Rare, occurring on sand bars of DAD and MOL. Newly reported species in Korea.

24. ${ }^{*}$ Fallacia plathii (Brockmann) Snoeijs in Snoeijs and Balashova 1998 (Pl. 7, Fig. 5) (Witkowski et al. 2000, p 210, pl. 70: 30). Basionym: Navicula plathii Brockmann 1950. L: $21 \mu \mathrm{m}$; B: $10 \mu \mathrm{m}$; S: 28/10. Very rare, only one frustule is found on the MOL beach. Newly reported in Korea.

25. Fallacia pygmaea (Kützing) Stickle \& Mann in Round et al. 1990 (Pl. 7, Fig. 17) (Witkowski et al. 2000, p 211, pl. 72: 28-30). Basionym: Navicula pygmaea Kützing

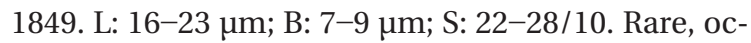
curring in some samples from the MOL, SON, and others, but the maximum relative abundance is $21 \%$ at the MOL beach.

26. *Fallacia scaldensis Sabbe \& Muylaert in Sabbe, Vyverman \& Muylaert 1999 (Pl. 6, Figs. 12, 13; Pl. 7, Fig. 29) (Sabbe et al. 1999, p 18. figs. 52-58, 71). L:

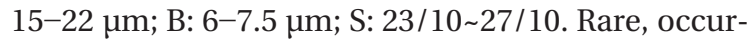
ring on two sand bars, i.e., the JIN and DOY. Newly reported in Korea.

27. *Fallacia schoemaniana (Foged) Witkowski, LangeBertalot \& Metzeltin 2000 (Pl. 7, Figs. 3, 4) (Witkowski et al. 2000, p 213, pl. 70: 14-19). Basionym: Navicula schoemaniana Foged 1975. L: 10-16 $\mu \mathrm{m}$; B: 6-8.5 $\mu \mathrm{m}$; S: 16-22/10. Very rare, occurring only on the MOL beach. Newly reported in Korea.

28. *Fallacia subforcipata (Hustedt) Mann in Round et al. 1990 (Pl. 6, Figs. 16, 17) (Witkowski et al. 2000, p 213, pl. 72: 20-23). Basionym: Navicula subforcipata

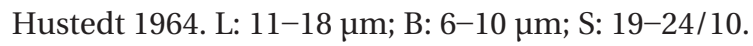
Common, occurring on all sand bars and beaches, but the relative abundances are very low or rare. Newly reported species in Korea.

29. Fallacia tenera (Hustedt) Mann in Round et al. 1990 (Pl. 7, Figs. 8-11) (Witkowski et al. 2000, p 214, pl. 71: 52-56). Basionym: Navicula tenera Hustedt in Schmidt et al. 1936. L: 6.5-19 $\mu \mathrm{m}$; B: 4-6.5 $\mu \mathrm{m}$; S: 17-18/10. Commonly occurring on the sand bars and beaches, most abundant on the northern slope of the BAK sand bar (72\%), followed by the SIN (17\%). 


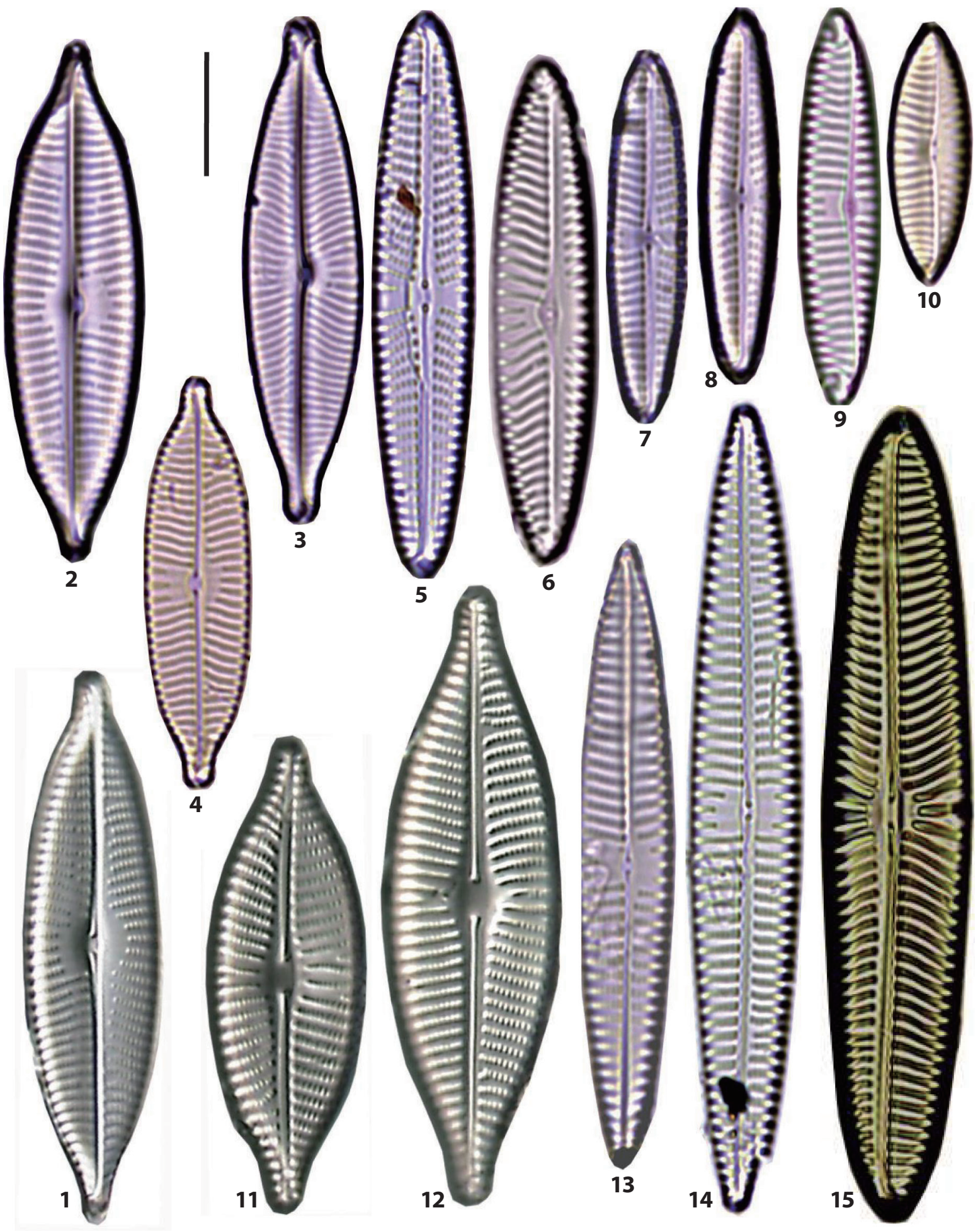

Plate 2. Figs. 1, 2. Navicula luciae. Fig. 3. N. rostellata. Fig. 4. N. amphiceropsis. Fig. 5. N. eidrigiana. Fig. 6. N. digitoconvergens. Figs. 7, 8. N. cincta. Figs. 9, 10. N. cancellata. Figs. 11, 12. N. iserentantii. Figs. 13, 14. N. directa. Fig. 15. N. digitoradiata. Scale bar, $10 \mu \mathrm{m}$. 
30. Fallacia sp. (Pl. 7, Figs. 23, 24) L: 14-15 $\mu \mathrm{m}$; B: $5.5 \mu \mathrm{m}$; S: 18-20/10. Very rare in DAD and MOL.

\section{Fogedia Witkowski, Lange-Bertalot, Metzeltin \& Bafana 1997}

31. Fogedia finmarchica (Cleve \& Grunow) Witkowski et al. 1997 (Pl. 4, Fig. 20) (Witkowski et al. 2000, p 217, pl. 63: 33-36). Synonym: Navicula finmarchica (Cleve \& Grunow) Cleve 1895. L: $38 \mu \mathrm{m}$; B: $10 \mu \mathrm{m}$; S: 16/10. Rare, occurring in a few samples from the JAN and other sand bars.

32. *Fogedia giffeniana (Foged) Witkowski, Lange-Bertalot, Metzeltin \& Bafana 1997 (Pl. 4, Fig. 19) (Witkowski et al. 2000, p 218, pl. 63: 1-9). Basionym: Navicula giffeniana Foged 1975. L: $33 \mu \mathrm{m}$; B: $11 \mu \mathrm{m}$; S: 12/10. Rare, occurring on the DAD and MOL beaches with very low abundance. Newly reported in Korea.

33. *Fogedia heterovalvata (Simonsen) Witkowski, Lange-Bertalot \& Metzeltin 2000 (Pl. 4, Fig. 17) (Witkowski et al. 2000, p 219, pl. 64: 8-18). Basionym: $\mathrm{Na}$ vicula heterovalvata Simonsen 1959. L: $17 \mu \mathrm{m}$; B: 7 $\mu \mathrm{m}$; S: 15/10. Very rare, occurring in the YEN. Newly reported in Korea.

34. *Fogedia krammeri Witkowski, Lange-Bertalot, Kociolek \& Kulikovskiy in Witkowski et al. 2010 (Pl. 4, Fig. 18) (Witkowski et al. 2010, p 50, figs. 1, 2). L: 24-44 $\mu \mathrm{m}$; B: 11-12.5 $\mu \mathrm{m}$; S: 13-14/10. Rare, occurring in a few samples from the DOY and other sand bars. Newly reported in Korea.

\section{Geissleria Lange-Bertalot \& Metzeltin 1996}

35. Geissleria decussis (Hustedt) Lange-Bertalot \& Metzeltin 1996 (Pl. 3, Fig. 14) (Lange-Bertalot 2001, p 123, pl. 95: 1-17, 96: 11). Basionym: Navicula decussis Østrup 1910. L: $22 \mu \mathrm{m}$; B: $6.5 \mu \mathrm{m}$; S: 13.5/10. Freshwater diatoms, occurring rarely from the JAN and the YEN.

\section{Haslea Simonsen 1974}

36. *Haslea spicula (Hickie) Lange-Bertalot 1997 (Pl. 4, Fig. 26) (Witkowski et al. 2000, p 231, pl. 97: 6). Synonym: Navicula spicula (Cleve \& Grunow in Grunow) Cleve 1894 (Krammer and Lange-Bertalot 1986, p 133, pl. 52: 5-6, 53: 1-2). L: $41 \mu \mathrm{m}$; B: $7.5 \mu \mathrm{m}$; S: invisible. Very rare, occurring on the northern slope of the BAK sand bar. Newly reported in Korea.

\section{Hippodonta Lange-Bertalot, Witkowski \& Met- zeltin 1996}

37. *Hippodonta avittata (Cholnoky) Lange-Bertalot, Metzeltin \& Witkowski 1996 (Pl. 4, Figs. 10-12; Pl. 7, Figs. 27, 28) (Lange-Bertalot 2001, p 97, pl. 76: 19-28). Basionym: Navicula subcostulata var. avittata Chol-

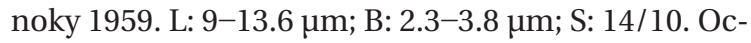
casionally, occurring in some samples from the SIN, DAD, MYN, and other sand flats. Newly reported in Korea.

38. Hippodonta hungarica (Grunow) Lange-Bertalot et al. 1996 (Pl. 4, Fig. 14) (Lange-Bertalot 2001, p 100, pl. 75: 7-12). Synonym: Navicula capiata var. hungarica (Grunow) Ross 1947. L: $27 \mu \mathrm{m}$; B: $6.5 \mu \mathrm{m}$; S: $10 / 10$. Frequent, occurring in $\geq 12$ samples from the BAK, JAN, JID, MYN, YEN, SON, and others, and the maximum abundance is $13 \%$ in the YEN, followed by $3 \%$ in the JID.

39. Hippodonta linearis (Østrup) Lange-Bertalot, Metzeltin \& Witkowski 1996 (Pl. 4, Fig. 13) (Witkowski et al. 2000, p 226, pl. 66: 13-16). Synonym: Navicula capitata var. linearis (Østrup) Kobayasi in Kobyasi et al. 1977. L: 22 m; B: $5.5 \mu \mathrm{m}$; S: 7.5/10 11/10. Rare, occurring in a few samples from the JAN, YEN, and others.

\section{Luticola Mann in Round et al. 1990}

40. Luticola cohnii (Hilse) Bukhtiyarova 1995. Synonym: Navicula mutica var. cohnii (Hilse) Grunow 1880 (Krammer and Lange-Bertalot 1986, p 152, pl. 63: 1-3). L: $27 \mu \mathrm{m}$; B: $10 \mu \mathrm{m}$; S: 16-18/10. Freshwater form, occurring rarely in the southern parts of the NAM sand bar.

41. Luticola mutica var. ventricosa (Kützing) Bukhtiyarova 1995 (Pl. 4, Figs. 5, 6). Synonym: Navicula mutica var. ventricosa (Kützing) Cleve \& Grunow 1880 (Krammer and Lange-Bertalot 1986, p 150, pl. 61: 9-11). L: 15-18 $\mu \mathrm{m}$; B: 6.5-7 $\mu \mathrm{m}$; S: 15-18/10. Rare, occurring in a few samples from the YEN and other sand-flats.

\section{Lyrella Karayeva 1978}

42. * Lyrella clavata (Gregory) Mann in Round et al. 1990 (Pl. 5, Fig. 7) (Witkowski et al. 2000, p 231, pl. 97: 6). Basionym: Navicula clavata Gregory 1856 (Hustedt 1961-1966, p 445, fig. 1509a-e). L: 35-57 m; B: 19-26 $\mu \mathrm{m}$; S: 11-15/10. Rare, occurring in a few samples 

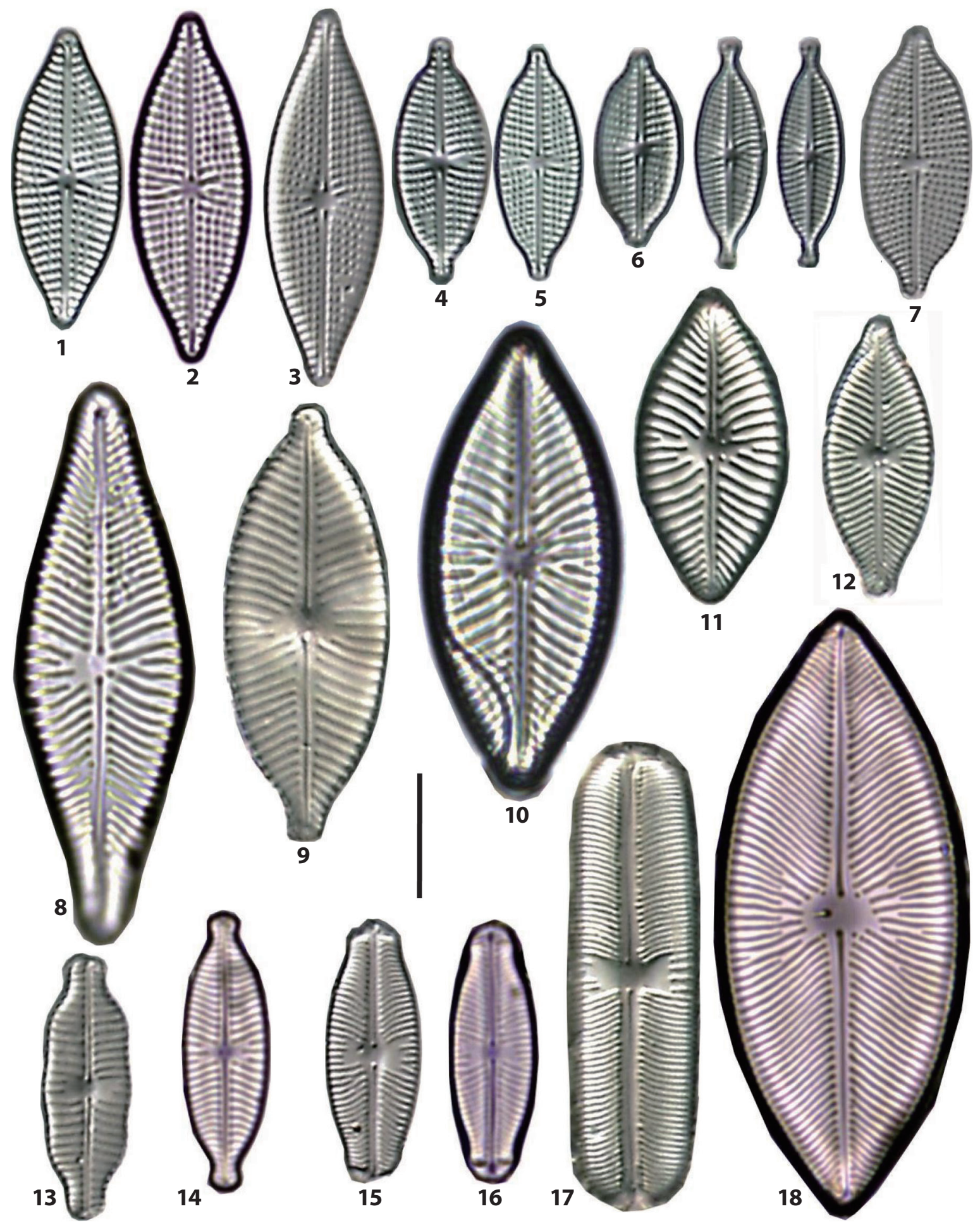

Plate 3. Figs. 1-3. Navicula torneensis. Figs. 4-6. N. cf. torneensis. Fig. 7. N. aff. besarensis. Fig. 8. P. rhombica. Fig. 9. Placosneis constans. Figs. 10, 11. P. clementis. Fig. 12. P. clementioides. Fig. 13. P. neglecta. Fig. 14. Geissleria decussis. Figs. 15, 16. Sellaphora pupula. Fig. 17. S. rectangularis. Fig. 18. Navicula flabellata. Scale bar, $10 \mu \mathrm{m}$. 
from the JIN, SIN, and other sand bars. Newly reported in Korea.

\section{Mayamaea Lange-Bertalot 1997}

43. Mayamaea atomus (Kützing) Lange-Bertalot 1997 (Pl. 4, Figs. 1, 2). Synonym: Navicula atomus (Kützing) Grunow 1860 (Mayama and Kobayasi 1988, p 429, figs. 1-40). L: 7.5-9.5 $\mu \mathrm{m}$; B: 3-5.5 $\mu \mathrm{m}$; S: invisible. Rare, occurring in two sand flats, i.e., the YEN and JAN.

\section{Moreneis Park, Koh \& Witkowski 2012}

44. Moreneis coreana Park, Koh \& Witkowski 2012 (Pl. 5, Figs. 5, 6) (Park et al. 2012, p 190, figs. 2a-l). L: 23-42

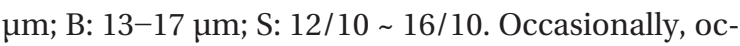
curring in some samples from the JAN, BAK, NAM, DOY, and other sand bars.

45. Moreneis sp. 01 (Pl. 4, Fig. 28). L: 27-45 بm; B: 15-16 $\mu \mathrm{m} ; \mathrm{S}: 12 / 10-16 / 10$. Rare, occurring on the southern slope of the DOY sand bar with $3 \%$ abundance of the naviculoid diatoms.

\section{Navicula Bory de Saint-Vincent 1822}

46. *Navicula agnita Hustedt 1955 (Pl. 1, Fig. 15) (Witkowski et al. 2000, p 266, pl. 136: 21, 142: 10). L: 41 $\mu \mathrm{m}$; B: $5.5 \mu \mathrm{m}$; S: 10/10 (14-16/10). Rare, occurring in a few samples from the JIN and other sand bars. The maximum abundance is $13 \%$. Newly reported species in Korea.

47. *Navicula amphiceropsis Lange-Bertalot \& Rumrich in Rumrich et al. 2000 (Pl. 2, Fig. 4) (Lange-Bertalot 2001, p 83, pl. 34: 8-15, 71: 2). L: 33 m; B: $8.5 \mu \mathrm{m}$; S: 11/10. Very rare, occurring in the YEN and others. Newly reported in Korea.

48. Navicula arenaria var. rostellata Lange-Bertalot 1985 (Pl. 1, Fig. 23) (Witkowski et al. 2000, p 267, pl. 116: 18-20, 129: 29). L: $40 \mu \mathrm{m}$; B: $6 \mu \mathrm{m}$; S: 11/10. Rare, occurring in some samples from the SIN and other sand bars.

49. Navicula cancellata Donkin 1872 (Pl. 2, Figs. 9, 10) (Witkowski et al. 2000, p 271, pl. 138: 1-3, 144: 1-7). L: 21-32 $\mu \mathrm{m}$; B: $6.5 \mu \mathrm{m}$; S: 10/10. Occasionally, occurring in eight samples from typical sand flats, i.e., the JIN, DOY, NAM, DAD, JID and others. The most abundant in the DAD (10-13\%), followed by the DOY $(8 \%)$ and the JID (3\%).

50. Navicula cincta (Ehrenberg) Ralfs in Pritchard 1861
(Pl. 2, Figs. 7, 8) (Lange-Bertalot 2001, p 26, pl. 41:

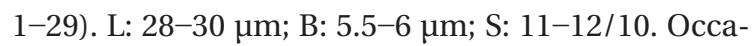
sionally, occurring in some samples from the BAK, YEN, and some other sand flats.

51. Navicula cryptocephala Kützing 1844 (Pl. 1, Fig. 14) (Lange-Bertalot 2001, p 27, pl. 17: 1-10, 18: 9-20). L: $29 \mu \mathrm{m}$; B: $5 \mu \mathrm{m}$; S: 14/10 17/10. Occasionally, occurring in some samples from the DOY, JAN, YEN, and others. The maximum abundance is $2 \%$.

52. ${ }^{*}$ Navicula digitoconvergens Lange-Bertalot 1999 (Pl. 2, Fig. 6) (Lange-Bertalot 2001, p 31, pl. 42: 7-14). L: $40 \mu \mathrm{m}$; B: $8 \mu \mathrm{m}$; S: 7/10 11/10. Very rare, occurring only on the NAM sand bar. Newly reported in Korea.

53. Navicula digitoradiata (Gregory) Ralfs in Pritchard 1861 (Pl. 2, Fig. 15) (Witkowski et al. 2000, p 274, pl.

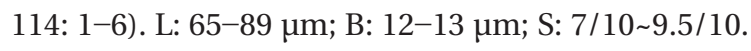
Occasionally, occurring in some samples from the DOY, BAK, SON, and others. The maximum abundance is $5 \%$.

54. Navicula directa (W. Smith) Ralfs in Pritchard 1861 (Pl. 2, Figs. 13, 14) (Witkowski et al. 2000, p 275, pl.

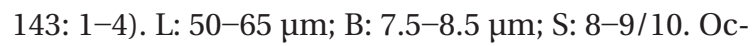
casionally, occurring in five samples from three sand bars, i.e., the DOY, DAD and MYN sand flat, with very low abundances.

55. *Navicula eidrigiana Carter 1979 (Pl. 2, Fig. 5) (Witkowski et al. 2000, p 276, pl. 121: 1-6, 133: 3-4). L: $46 \mu \mathrm{m}$; B: $8 \mu \mathrm{m}$; S: 10/10. Very rare, occurring on the northern slope from the BAK sand bar. Newly reported in Korea.

56. Navicula erifuga Lange-Bertalot 1985 (Pl. 1, Figs. 28, 29) (Krammer and Lange-Bertalot 1986, p 116, pl. 38 : 5-9). L: $40 \mu \mathrm{m}$; B: $6 \mu \mathrm{m}$; S: 11/10. Frequently, occurring in 12 samples from the BAK, JAN, YEN, JID, MYN, and other sand flats, and the orders of the abundance the YEN (38\%), BAK (7\%) and MYN (9\%).

57. *Navicula gerloffii Schimanski 1978 (Pl. 1, Fig. 30) (Krammer and Lange-Bertalot 1986, p 212, pl. 80: 18-21). L: $22 \mu \mathrm{m}$; B: $6 \mu \mathrm{m}$; S: invisible. Only one frustule in the YEN. Newly reported species in Korea.

58. ${ }^{*}$ Navicula germainii Wallace 1960 (Pl. 1, Fig. 22) (Lange-Bertalot 2001, p 85, pl. 38: 8-18, 64: 4, 71: 4). Synonym: Navicula viridula var. germainii (Wallace) Lange-Bertalot 1993. L: 28 m; B: $7 \mu \mathrm{m}$; S: 13-15/10. Very rare, occurring on the northern slope of the BAK. Newly reported in Korea.

59. Navicula gregaria Donkin 1861 (Pl. 1, Figs. 18-21; Pl. 7, Fig. 31) (Lange-Bertalot 2001, p 85, pl. 38: 8-18, 64:

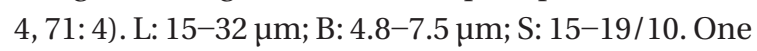
of the most common species in the intertidal area of 


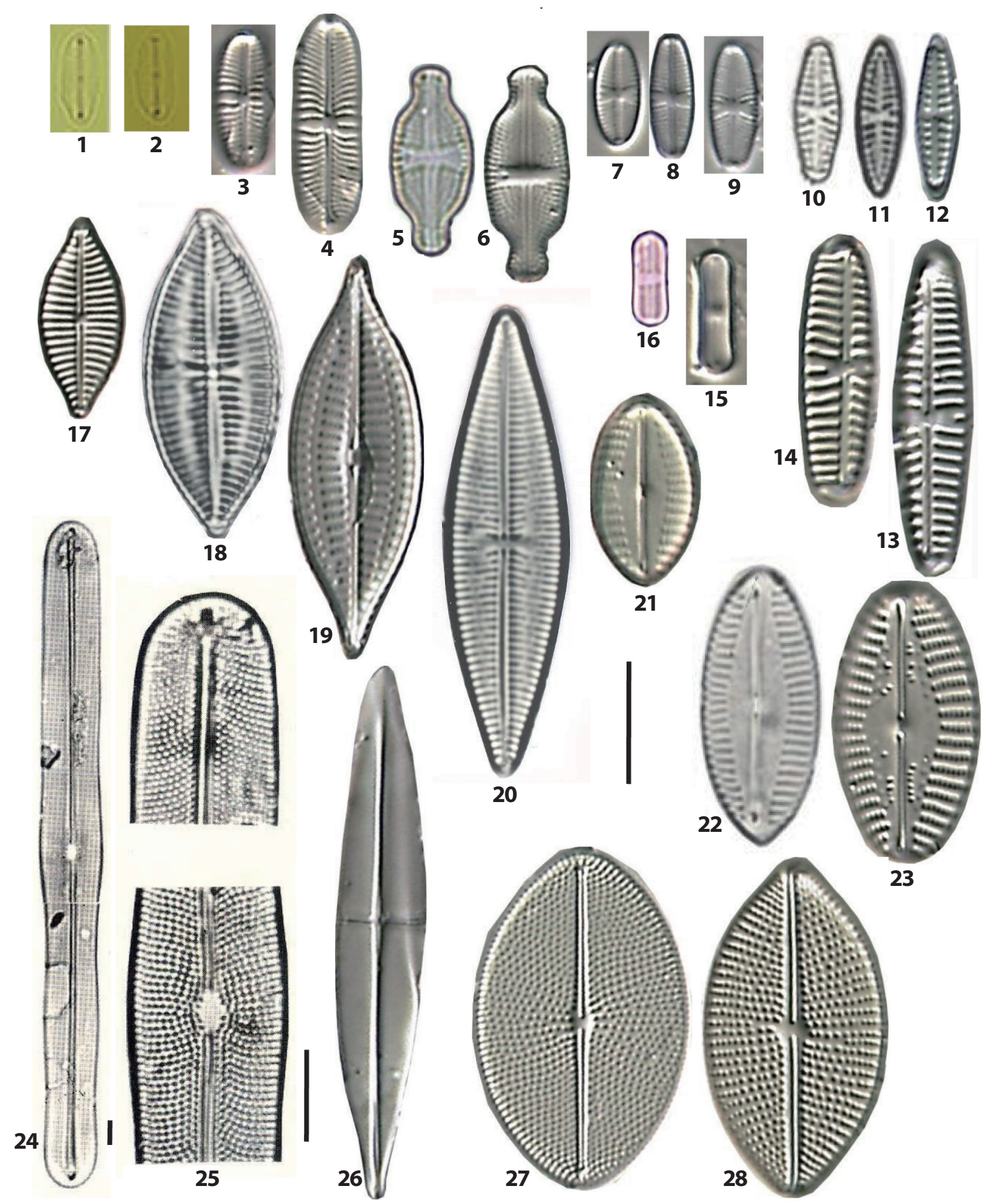

Plate 4. Figs. 1, 2. Mayamaea atomus. Figs. 3, 4. Dickieia ulvacea. Figs. 5, 6. Luticola mutica var. ventricosa. Figs. 7-9. Eolimna minima. Figs. $10-12$. Hippodonta avittata. Fig. 13. H. linearis. Fig. 14. H. hungarica. Figs. 15, 16. Diadesmus contenta. Fig. 17. Fogedia heterovalavta. Fig. 18. F. krammeri. Fig. 19. F. giffeniana. Fig. 20. F. finmarchica. Fig. 21. Austariella admissa. Fig. 22. A. jamalinenesis. Fig. 23. Austariella sp. 69. Figs. 24, 25. Berkeleya scopulorum (Fig. 24, x400; Fig. 25, x1500). Fig. 26. Haslea spicula. Fig. 27. Cocconeiopsis kantsinensis. Fig. 28. Moreneis sp. 01. Scale bars, $10 \mu \mathrm{m}$. 
the Nakdong River estuary, occurring in 25 of 32 sites. The orders of relative abundances are as followed, $13 \%$ in the DOY and NAM, $11 \%$ in the YEN, $10 \%$ in the BAK and $\leq 10 \%$ in the remaining sites. Before the estuarine dam construction, $N$. gregaria was the first dominant taxa in benthic diatom assemblages in the freshwater zones of the river mouth (Cho 1988).

60. ${ }^{*}$ Navicula iserentantii Lange-Bertalot \& Witkowski 2000 (Pl. 2, Figs. 11, 12) (Witkowski et al. 2000, p 284,

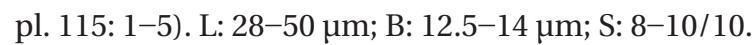
Rare, occurring only on the northern slope from the NAM sand bar. Newly reported in Korea

61. ${ }^{*}$ Navicula luciae Witkowski \& Lange-Bertalot in Lange-Bertalot and Genkal 1999 (Pl. 2 Figs. 1, 2) (Witkowski et al. 2000, p 288, pl. 17: 7-10) L: 39-44.5 $\mu \mathrm{m}$; B: 10-11 $\mu \mathrm{m}$; S: 8-9/10. Rare, occurring in only the BAK sand bar, with very low abundance. Newly reported in Korea.

62. Navicula perminuta Grunow in Van Heurck 1880 (Pl. 1, Figs. 1-3) (Lange-Bertalot 2001, p 54, pl. 33: 20-27). L: $8.2-14 \mu \mathrm{m}$; B: $2.6-4 \mu \mathrm{m}$; S: $14-16 / 10$. The most common and dominant species among the benthic diatoms of the intertidal area. The orders of dominance are as follows, DOY (88\%), JID (48\%), NAM and BAK (59\%), MYN (45\%), DAD (43\%), SIN (33\%), BAK ( $26 \%)$, NAM (25\%), JAN (22\%), SON (14\%), and $\leq 10 \%$ for the remaining sites.

63. *Navicula perrhombus Hustedt ex Simonsen 1987 (Pl. 1, Figs. 10, 11) (Witkowski et al. 2000, p 298. pl. 141: 24-26). L: $23-34 \mu \mathrm{m}$; B: 10-11 $\mu \mathrm{m}$; S: 9/10 11/10. Occasionally, occurring in some samples from the JAN, YEN, JID, and other sand flats. Newly reported in Korea.

64. *Navicula pseudosalinarioides Giffen 1975 (Pl. 1, Figs. 4, 5) (Witkowski et al. 2000, p 300, pl. 130: 20-22). L: 10-13.5 $\mu \mathrm{m}$; B: 5-5.5 $\mu \mathrm{m}$; S: 18-20/10. Rare, occurring in three samples from the DOY, NAM and SON sand flats, with very low abundances. Newly reported species in Korea.

65. Navicula recens (Lange-Bertalot) Lange-Bertalot 1985 (Pl. 1, Figs. 16, 17) (Lange-Bertalot 2001, p 62, Pl. 1: 16-22). L: 19-44 $\mu \mathrm{m}$; B: 6-8 $\mu \mathrm{m}$; S: 12-13.6/10. Occasionally, occurring in some samples from the SIN, JAN, MYN, and others, and the maximum abundance is $8 \%$.

66. Navicula rostellata Kützing 1844 (Pl. 2, Fig. 3) (LangeBertalot 2001, p 91, pl. 35: 1-6). Synonym: Navicula viridula var. rostellata (Kützing) Cleve 1895. L: 31-45 $\mu \mathrm{m}$; B: 9-10.5 $\mu \mathrm{m}$; S: 8-13/10. Frequently, occurring in the JIN, YEN, DOY, JAN, and others; the relative abundances are $\leq 6 \%$.

67. Navicula salinarum Grunow 1880 (Pl. 1, Figs. 24, 25) (Lange-Bertalot 2001, p 65, pl. 45: 1-8). L: 31-36 $\mu \mathrm{m}$; B: $10-11.5 \mu \mathrm{m}$; S: 13.5-15/10. Occasionally, occurring in five samples, and very abundant on the YEN sand flat with $55 \%$ relative abundance.

68. *Navicula salinarum var. minima Kolbe 1927 (Pl. 1, Fig. 27) (Lange-Bertalot 2001, p 65, pl. 45: 15-19). L: 21.5-26.5 $\mu \mathrm{m}$; B: 7-8 $\mu \mathrm{m}$; S: 16-17/10. Rare, occurring in only a single site, the YEN. Newly reported in Korea.

69. *Navicula salinarum var. rostrata (Hustedt) LangeBert 2001 (Pl. 1, Fig. 26) (Lange-Bertalot 2001, p 65, pl. 45: 9-14). L: $28 \mu \mathrm{m}$; B: $10 \mu \mathrm{m}$; S: 15/10. Rare, occurring at only one site, the YEN. Newly reported in Korea.

70. Navicula schroeteri Meister 1932 (Lange-Bertalot

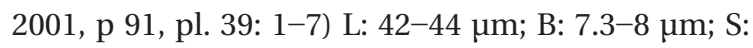
11-12/10. Brackish species, but very rare, occurring in one sample from the JAN sand bar.

71. Navicula tridentula Krasske 1923 (Pl. 1, Fig. 12) (Krammer and Lange-Bertalot 1986, p 210, pl. 80:

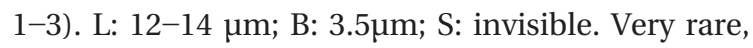
occurring in only one sample from the JAN sand bar.

72. Navicula tripunctata (O.F. Müller) Bory 1822 (Pl. 1, Fig. 13) (Lange-Bertalot 2001, p 73, pl. 1: 1-8, 67: 3, 4). L: $30 \mu \mathrm{m} ; \mathrm{B}: 6 \mu \mathrm{m} ; \mathrm{S}: 12 / 10$. Rare, occurring in two samples from the YEN and MYN sand flat, with very low abundance.

73. Navicula veneta Kützing 1844 (Pl. 1, Figs. 8, 9) (LangeBertalot 2001, p 78, pl. 14: 23-30, 65: 3). L: 11-22 $\mu \mathrm{m}$; B: $4.5-5 \mu \mathrm{m}$; S: $18 / 10$. Rare in some samples from the JAN and a few sand bars.

74. *Navicula viminoides Giffen 1975 (Pl. 1, Figs. 6, 7) (Witkowski et al. 2000, p 315, pl. 136: 27-33). L: 9-11.5 $\mu \mathrm{m}$; B: 4-4.5 $\mu \mathrm{m}$; S: 15/10. Commonly, occurring in many samples, and Abundance orders are as follows, the SON (14\%), DAD (10\%), BAK (4\%) and DOY (3\%). Newly reported species in Korea.

75. Navicula alpha Cleve 1893 (Pl. 5, Fig. 12) (Hustedt

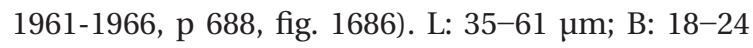
$\mu \mathrm{m} ; \mathrm{S}:(8-10 / 10) \sim 12 / 10$. Occasional, occurring in some sand bars, but the abundance very low or rare. Variable forms (Pl. 5, Fig 11, 13-15) different with the typical N. alpha are found frequently in the sandflats, and further examination is required for the taxonomic clarification.

76. ${ }^{*}$ Navicula forcipata var. densestriata A. Schmidt in A. Schmidt et al. 1881 (Pl. 6, Figs. 10, 11) (Schmidt 1881,

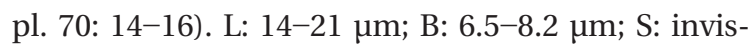



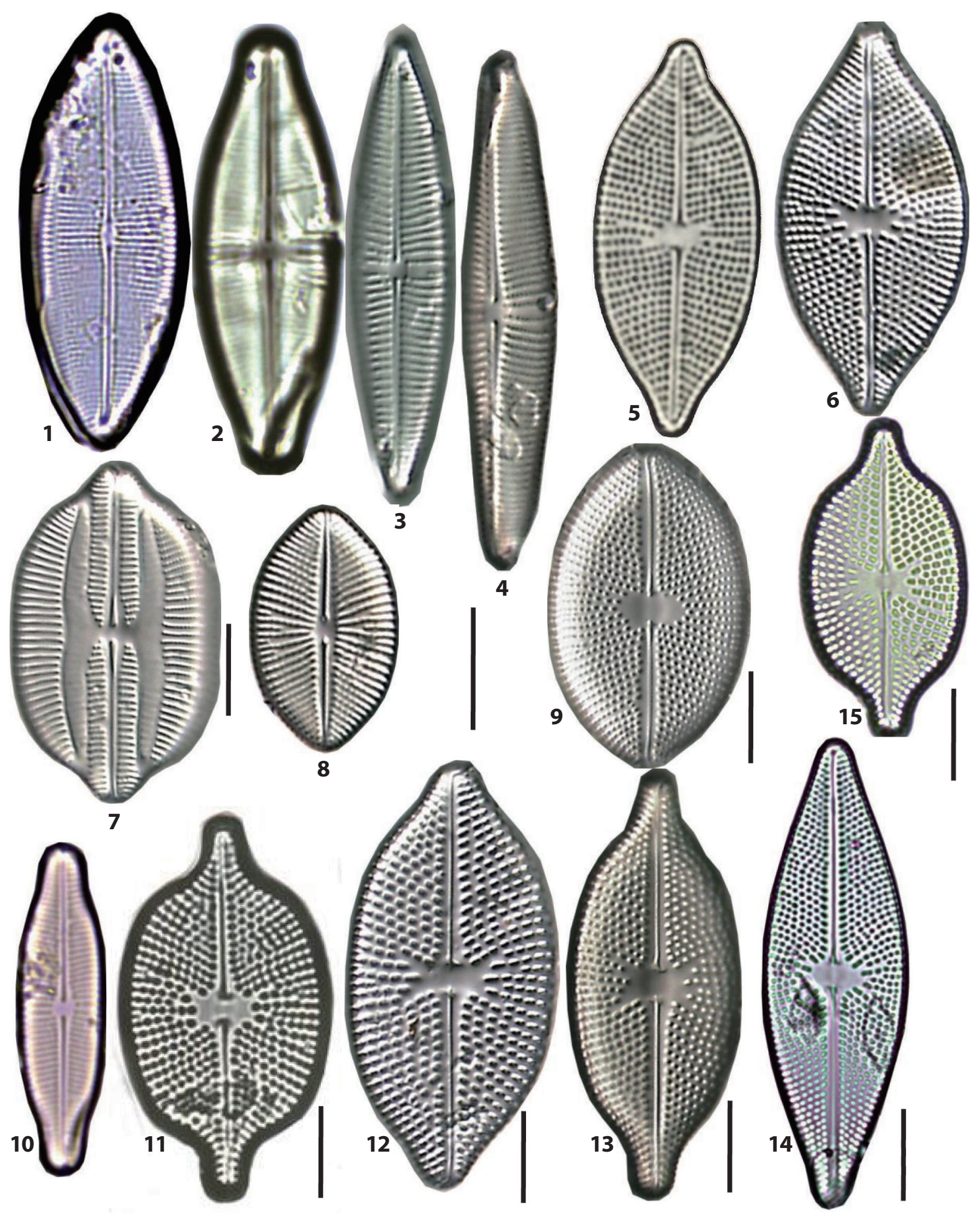

Plate 5. Fig. 1. Parlibellus delognei. Fig. 2. P. crucicula. Figs. 3, 4. P. ceuciculoides. Figs. 5, 6. Moreneis coreana. Fig. 7. Lyrella clavata (x1500). Fig. 8. Cosmioneis eta. Fig. 9. Petroneis marina (x1500). Fig. 10. Parlibellus protracta. Fig. 12. Navicula alpha (x1500). Figs. 11, 13-15. Different forms with the typical N. alpha (x1500). Scale bars, $10 \mu \mathrm{m}$. 
ible. Occasionally, occurring in five samples from two sand bars, the JAN and JID; the maximum abundance is $19 \%$ in the JAN sand bar. Newly reported species in Korea.

77. *Navicula flabellata Meister 1932 (Pl. 3, Fig. 18) (Schmidt 1936, pl. 405: 12). L: 34-49 $\mu \mathrm{m} ; \mathrm{B}: 15-20 \mu \mathrm{m}$; S: $(10-13 / 10) \sim(15-18 / 10)$. Very rare, occurring in two samples, the JAN and MOL sand flat. The relative abundance is $\leq 1 \%$. Newly reported species in Korea.

78. *Navicula torneensis Cleve 1891 (Pl. 3, Figs. 1-3; Pl. 7, Fig. 30) (Cleve-Euler 1953, p 120, fig. 740A). L: 15-30 $\mu \mathrm{m}$; B: 7-9.5 $\mu \mathrm{m}$; S: 13/10. The most common species, occurring in most samples. The order of the relative abundances is JAN (22-87\%), NAM (6-64\%), BAK (4-61\%), DOY (24-46\%), JIN (20\%), DAD (17\%), and SIN (14\%). The group diatoms vary in term of their valve shape and the strial density (Pl. 3, Figs. $1-7$ ), and some may be separated into new varieties or species. This taxon resembles Aneumastus minor (Hustedt) Lange-Bertalot (Lange-Bertalot 2001, p 155, pl. 124, figs. 1-16), but differ in some morphological features, apically slit-formed areolae and apically linear arrangement of areolae, and the straight raphe lines (Pl. 7, Fig. 30). Newly reported in Korea.

\section{Parlibellus Cox 1988}

79. Parlibellus crucicula (W. Smith) Witkowski, LangeBertalot \& Metzeltin 2000 (Pl. 5, Fig. 2) (Witkowski et al. 2000, p. 321, pl. 103: 11-13). Synonym: Navicula crucicula (W. Smith) Donkin 1871. L: $37 \mu \mathrm{m}$; B: 12 $\mu \mathrm{m} ; \mathrm{S}: 18-20 / 10$. Very rare in the freshwater zone in the estuary.

80. Parlibellus cruciculoides (Brockmann) Witkowski, Lange-Bertalot \& Metzeltin 2000 (Pl. 5, Figs. 3, 4) (Witkowske et al. 2000, p 321, pl. 134: 17-20). Basionym: Navicula cruciculoides Brockmann 1950. L: 22-39

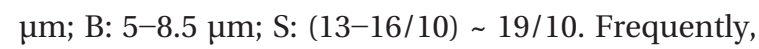
occurring in 15 samples from six sand bars, i.e., the DOY, BAK, JAN, JID, MYN and SON; the abundances are $\leq 6 \%$.

81. *Parlibellus delognei (Van Heurck) Cox 1988 (Pl. 5, Fig. 1) (Witkowski et al. 2000, p 321, pl. 104: 1-5) Basionym: Navicula grevillei (Agardh) Heiberg 1863. Synonym: Navicula delognei Van Heurck 1880. L: $35.5 \mu \mathrm{m}$; B: $11 \mu \mathrm{m}$; S: 20/10. Very rare, occurring only on the southern slope from the DOY sand bar. Newly reported in Korea.

82. Parlibellus protracta (Grunow) Witkowski, LangeBertalot \& Metzeltin 2000 (Pl. 5, Fig. 10) (Witkowske et al. 2000, p 324, pl. 134: 13, 14). Basionym: Navicula protracta Grunow 1880. L: 26-28 $\mu \mathrm{m}$; B: $7 \mu \mathrm{m}$; S: 16-20/10. Rare, occurring in two sand bars, the YEN and DAD, with very low abundances.

\section{Petroneis Sticke \& Mann in Round et al. 1990}

83. Petroneis granulata (Bailey) Mann in Round et al. 1990 (Pl. 6, Fig. 2) (Witkowski et al. 2000, p 327, pl. 97: 1, 2). Basionym: Navicula granulata Bailey 1854. L: $32 \mu \mathrm{m} ; \mathrm{B}: 17 \mu \mathrm{m} ; \mathrm{S}: 10 / 10$. Very rare, occurring rarely in the SON and a few area.

84. Petroneis humerosa (Brébisson) Stickle \& Mann in Round et al. 1990 (Pl, 6. Fig. 3) (Witkowski et al. 2000, p 327, pl. 101: 2-3, 103: 3). Basionym: Navicula humerosa Brébisson ex W. Smith 1856. L: 53-55 $\mu \mathrm{m}$; B: 25-26 $\mu \mathrm{m}$; S: 12/10 16/10. Very rare, occurring in only the JAN sand bar.

85. Petroneis marina (Ralfs) Mann in Round et al. 1990 (Pl. 5, Fig. 9) (Witkowski et al. 2000, p 328, pl. 102: 1). Basionym: Navicula marina Ralfs in Pritchard 1861.

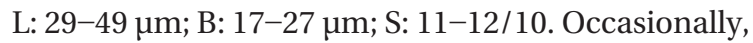
occurring in five samples from the SIN, BAK, and JAN sand bar, with very low abundance.

\section{Placoneis Mereschkowsky 1903}

86. Placoneis clementis (Grunow) Cox 1987 (Pl. 3, Figs. 10, 11). Basionym: Navicula clementis Grunow 1882 (Krammer and Lange-Bertalot 1986, p 139, pl. 47: 1-9). L: 22-38 $\mu \mathrm{m}$; B: 11-15 $\mu \mathrm{m}$; S: 8/10 13/10. Occasionally, occurring in eight samples from the DOY, NAM, JAN, and YEN sand flat; the abundance is $\leq 6 \%$.

87. *Placoneis clementioides (Hustedt) Cox 1987 (Pl. 3, Fig. 12). Basionym: Navicula clementioides Hustedt 1944 (Krammer and Lange-Bertalot 1986, p 140, pl. 48: 3-8). L: $22 \mu \mathrm{m}$; B: $8.5 \mu \mathrm{m}$; S: 14/10 18/10. Very rare, occurring on the northern slope of the NAM. Newly reported in Korea.

88. *Placoneis constans (Hustedt) Cox 2003 (Pl. 3, Fig. 9). Basionym: Navicula constans Hustedt 1944 (Krammer and Lange-Bertalot 1986, p 140, pl. 48: 10-14). L: $35 \mu \mathrm{m}$; B: $13 \mu \mathrm{m}$; S: 10/10 12/10. Only one frustule on the YEN sand-flat. Newly reported in Korea.

89. Placoneis neglecta (Krasske) Tuji 2003 (Pl. 3, Fig. 13). Synonym: Navicula neglecta Krasske 1929 (Krammer and Lange-Bertalot 1986, p 136, pl. 46: 8, 9). L: $22 \mu \mathrm{m}$; B: $7 \mu \mathrm{m}$; S: 13/10. Very rare, occurring on the YEN and JAN sand flat.

90. *Placoneis rhombica (Brockmann) Lange-Bertalot 

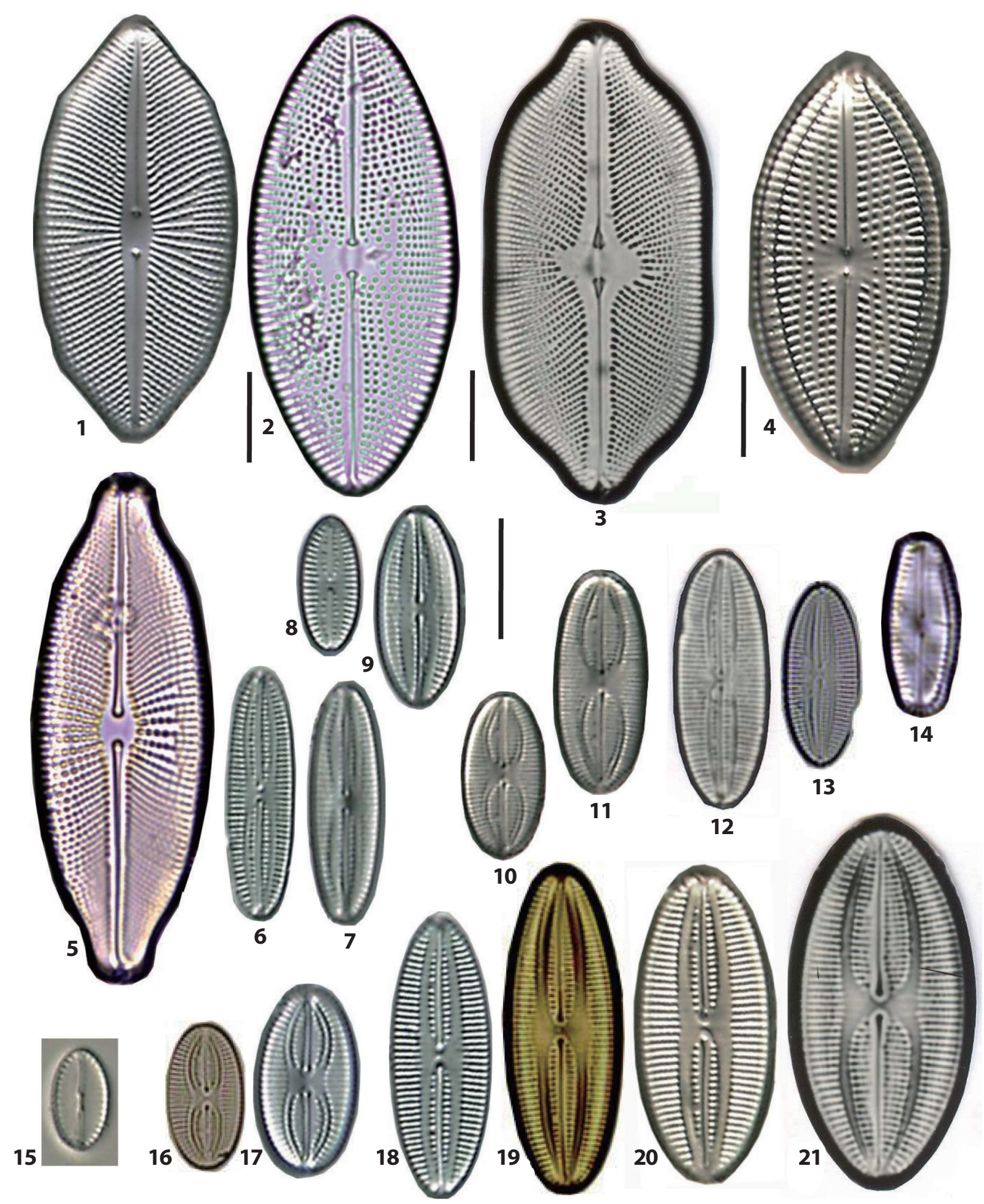

Plate 6. Fig. 1. Cosmioneis eta. Fig. 2. Petroneis granulata (x1500). Fig. 3. P. humerosa (x1500). Fig. 4. Diademoides luxuriosa (x1500). Fig. 5. Cosmioneis grossepunctata. Figs. 6-9. Fallacia litoricola. Figs. 10, 11. Navicula forcipata var. densestriata. Figs. 12, 13. Fallacia scaldensis. Fig. 14. Chamaepinnularia clamans. Fig. 15. Fallacia amphipleuroides. Figs. 16, 17. F. subforcipata. Figs. 18-21. F. forcipata. Scale bars, $10 \mu \mathrm{m}$. 


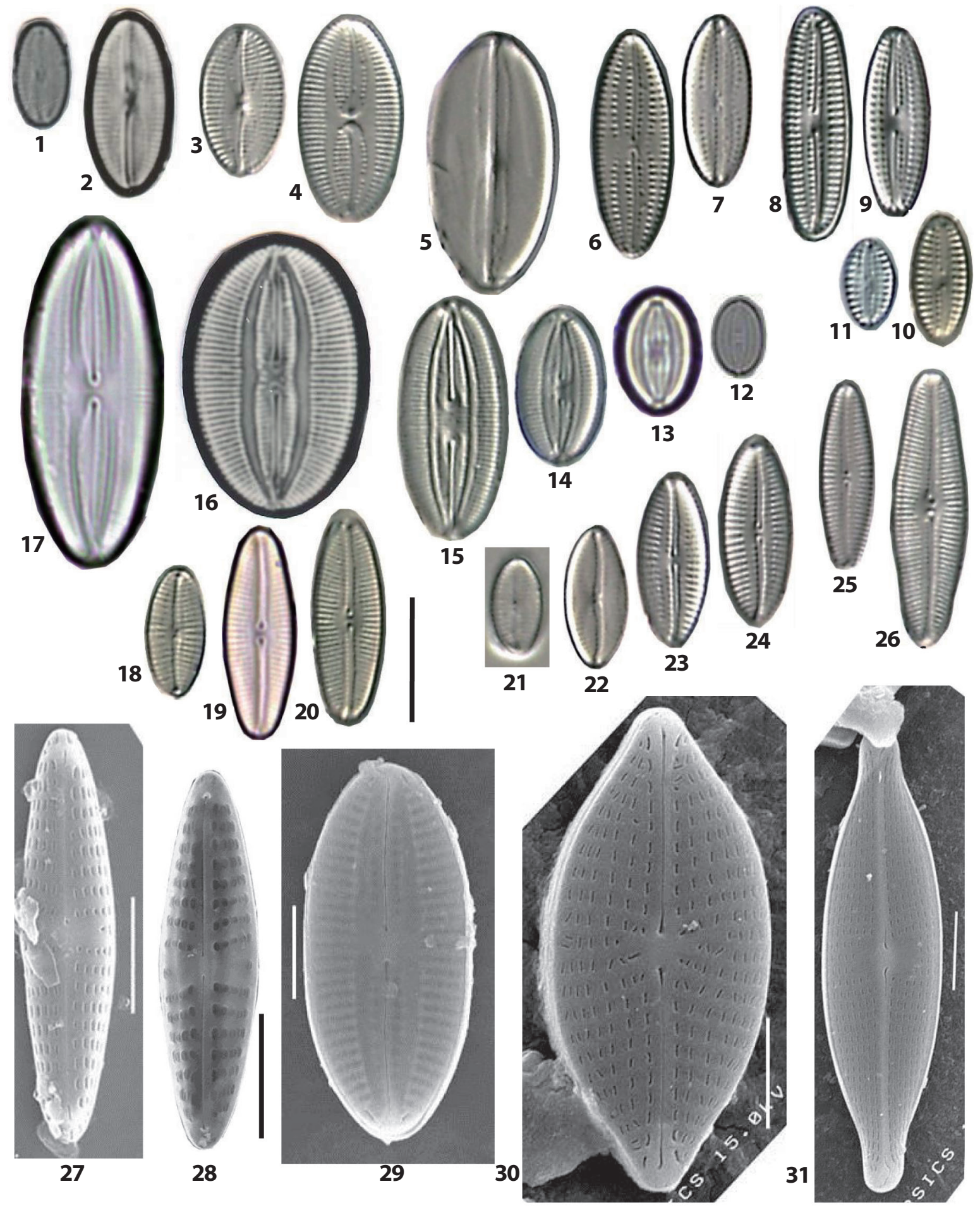

Plate 7. Figs. 1, 2. F. cryptolyra. Figs. 3, 4. F. schoemaniana. Fig. 5. F. plathii. Figs. 6, 7. F. dithmarsica. Figs. 8-11. F. tenera. Figs. 12-15. F. florinae. Fig. 16. F. nyella. Fig. 17. F. pygmaea. Figs. 18-20. F. omissa. Figs. 21, 22. F. cunoniae. Figs. 23, 24. F. sp. Figs. 25, 26. F. gemmifera. Scale bar (Figs. 1-26), $10 \mu$ m. Figs. 27-31. Images under SEM (Scale bars, 3 Hm). Figs. 27, 28. Hippodonta avittata. Fig. 29. Fallacia scaldensis. Fig. 30. Navicula torneensis. Fig. 31. N. gregaria. 
in Metzeltin, Lange-Bertalot and García-Rodríguez 2005 (Pl. 3, Fig. 8). Basionym: Navicula clementis var. rhombica Brockmann 1950 (Krammer and LangeBertalot 1986, p 139, pl. 47: 6). Only one frustule on the southern slope of the DOY sand bar. Newly reported in Korea.

\section{Sellaphora Mereschkowsky 1902}

91. Sellaphora rectangularis (Gregory) Lange-Bertalot \& Metzeltin 1996 (Pl. 3, Fig. 17) (Lange-Bertalot and Metzeltin 1996, p 102, pl. 25: 10-12, 125: 7). Synonym: Navicula pupula f. rectangularis (Gregory) Hustedt 1961. L: $38 \mu \mathrm{m}$; B: $10.5 \mu \mathrm{m}$; S: 19/10. Very rare, occurring on a sand flat of the YEN.

92. Sellaphora pupula (Kützing) Mereschkowsky 1902 (Pl. 3, Figs. 15, 16). Basionym: Navicula pupula Kützing 1844 (Krammer and Lange-Bertalot 1986, p 189, pl. 68: 1-2). L: $27-28 \mu \mathrm{m}$; B: 7.8-8.5 $\mu \mathrm{m}$; S: 18-24/10. Rare, occurring in two samples from two areas, the YEN and JAN.

Ninety-two naviculoid diatom species are encountered through the sampling periods. They are found to belong to 23 genera, which included the old genus Navicula, but is currently revised as a new genus. The richest genera containing many species are ordered in decreasing order as follows: Navicula of 33 species and varieties, Fallacia of 17 species, Placoneis of five species, Fogedia and Parlibellus of four species, Austariella, Hippodonta and Petroneis of three species, Cosmioneis, Diadesmis, Luticola, Moreneis and Sellaphora of two species and variety, Berkeleya, Chamaepinnularia, Cocconeiopsis, Diademoides, Dickieia, Eolimna, Geissleria, Haslea, Lyrella and Mayamaea of one species. The dominant species in all 32 samples in 12 areas in the estuary are Navicula perminuta, N. gregaria, N. torneensis, and Fallacia subforcipata. The important diatom groups in the naviculoid diatom flora, dominant at least in one sample, include eight taxa (i.e., Navicula salinarum, Navicula viminoides, Fallacia cunoniae, $F$ litoricola, F. tenera, Fallacia pygmaea, Navicula forcipata var. densestriata, Navicula erifuga). The abundance of each species fluctuates depending on the sampling site, and abundance in a certain sampling site varies depending on the season. Some species are found in only one sample and observed by a single individual. As this study focuses on the naviculoid diatoms, the occurring percentages of the naviculoids in the diatom assemblages range widely from $5 \%$ (on the southern slope of the DOY sand bar) to $75 \%$ (on the northern slope of the DOY sand bar); the mean number is $27 \%$. Although a few unidentified diatoms are illustrated in this floristic study, the more diatoms remain unidentified.

\section{DISCUSSION}

The naviculoid diatoms in the sandy sediment of the Nakdong River estuary are abundant, and the floral compositions are highly diverse. The floral composition at the Nakdong River estuary show great similarity to those of the other regions (e.g., northern and eastern Europe (Hustedt and Aleem 1951, Aleem 1973, Ribeiro et al. 2003) and northern America (Amspoker 1977a). The Fallacia species at the Nakdong are more diverse than in at any other region. The benthic diatom assemblages in this study are characterized by the colonization of a few dominant or frequent species and many occasional or rare species. In particular, the Navicula sensu stricto and Fallacia taxa are the most rich in naviculoids flora and the most abundant in cell counts. Fallacia is known to be the most diverse component of benthic assemblages in brackish and marine sand-flats worldwide (Sabbe et al. 1999). Naviculoid species compositions of diatom assemblages are not stable across the sampling sites and times, being dominated by same taxa throughout the sampling periods, and fluctuations of the dominant taxa are more pronounced in the local area.

Navicula gregaria is one of the most important species at the Nakdong, and has been reported as the leading species in many countries (Round 1960, Amspoker 1977a, Sabbe 1993, Underwood et al. 1998, Ribeiro et al. 2003, Underwood and Barnett 2006). This species is tolerant of nutrient-rich conditions or eutrophication under the effects of discharge from sewage treatment plants (Agatz et al. 1999). This diatom taxon is classified as an oligohaline, a highly mobile, and epipelic species rather than an attached form (Sabbe 1993). N. perminuta has been recorded as the dominant taxon in many regions (Méléder et al. 2007), and Fallacia tenera has also been reported as important species in the some localities (Méléder et al. 2007). Dominant taxa, which are highly ranked in frequence and abundance, show the wide range of morphological variations, particularly, in the dimensions and strial punctas on the valve are varied. They are Navicula and Fallacia group, e.g., N. gregaria, N. perminuta, N. torneenensis and Fallacia tenera.

In addition to the naviculoid taxa, the overall diatom assemblages of this estuary exhibited a high diversity in floral composition and are composed of $>450$ taxa, in- 
cluding unidentified taxa. The species composition levels change significantly across most stations and sampling times, and the dominant species also vary according to the stations and times. The most important species in all the 32 samples are primarily biraphid diatoms (i.e., $\mathrm{Na}$ vicula perminuta, $N$. salinarum, $N$. torneensis, some unidentified Navicula and Amphora species, an unidentified Nitzschia species, Hantzschia virgata and Amphipleura rutilans). Monoraphid diatoms such as Achnanthes delicatula and two unidentified Cocconeis species, are present in some samples, and an araphid taxon of an unidentified Fragilaria is dominant in one sample from the MYN sand-flats. At one sampling site, the floral composition and its dominant species significantly differs with sampling times. These microbiotic differences may reflect the variable conditions of the tidal environments and their dynamics in estuarine ecosystems.

The intertidal sand-flats in the estuary are open systems and connected to freshwater and seawater sources. Diatoms may be recruited from two sources, e.g., freshwater diatoms from rivers, planktons from the ocean and attached diatoms from the rocky shore (Aleem 1950). Although the recruited diatoms are likely to be centric diatoms, Stephanodiscus and Aulacoseira species from the freshwater area of the Nakdong River and the Seonakdong River, and Skeletonema, Chaetoceros and Thalassiosira diatoms off the coast, these exotic planktons of centric diatoms scarcely occur in microbiotic assemblages of the sand-flats. Diatoms encountered in the sand-flats are almost primarily independent of the planktons and endemic to the sandy sediments, possessing epipsammic or epipelic habits. Although this study was confined to the intertidal or littoral area of the estuary, some sites, such as the YEN, JID, and MYN, are under the influence of freshwater sources. The endemic species to freshwater area are often observed across the three sites with occasional or frequent occurrences.

Benthic diatom flora are unique to tidal environments and more rich when compared to other diatom assemblages in brackish and marine environments (Round 1971). Although benthic diatoms were first described in the 18th century, they have been intensively studied since the 1930s in northern Europe (Round 1971), when benthic research expanded over the northern America and into other regions of the world. In many researches, the number of diatom taxa occurring in the mudflats or salt marshes of the coastal or estuarine area typical range from 130-190 species and varieties (Hustedt and Aleem 1951, Drum and Webber 1966, Aleem 1973, Riznyk 1973, Rao and Lewin 1976, DeFelice and Lynts 1978). In inten- sive studies and frequent samplings, $\geq 390$ taxa have been counted by microscopic observations (Hustedt 1939, Amspocker 1977a). However, lower floristic compositions, from 74-97 taxa, have been reported by some studies of benthic sediments in coastal areas (Round 1960, Stidolph 1985, Kosugi 1987, Sabbe 1993, Méléder et al. 2007).

It is found that the benthic diatom assemblages are composed of diverse taxa in the naviculoid group as well as in the community level, and they are attached or motile forms. The dynamic environments in the estuary would support the diversity of the diatom assemblages. The present study will directly provide an assistant to the identification of diatom taxa and contribute to the ecological interpretation of the microphytobenthos in the intertidal area.

\section{ACKNOWLEDGMENTS}

This work was supported by a grant from the National Institute of Biological Resources (NIBR), funded by the Ministry of Environment (MOE) of the Republic of Korea (NIBR No. 2013-01-001).

\section{LITERATURE CITED}

Agatz M, Asmus RM, Deventer B. 1999. Structural changes in the benthic diatom community along a eutrophication gradient on a tidal flat. Helgol Mar Res 53: 92-101.

Aleem AA. 1950. Distribution and ecology of British marine littoral diatoms. J Ecol 38: 75-106.

Aleem AA. 1973. Contribution to the study of littoral diatoms on the West Coast of Sweden. Bot Mar 16: 193-200.

Al-Handal AY, Wulff A. 2008. Marine benthic diatoms from Potter Cove, King George Island, Antarctica. Bot Mar 51: 51-68.

Amspocker MC. 1977a. The distribution of intertidal diatoms associated with the sediments of Yaquina Estuary, Oregon. PhD dissertation. Oregon State University, Corvallis, OR, USA.

Amspocker MC. 1977b. The distribution of intertidal epipsammic diatoms on Scripps Beach, La Jolla, California, USA. Bot Mar 20: 227-232.

Amspocker MC, McIntire CD. 1978. Distribution of intertidal diatoms associated with sediments in Yaquina Estuary, Oregon. J Phycol 14: 387-395.

Cho KJ. 1988. The community structure of benthic diatoms along the environmental gradient of sediment from the Nakdong River estuary, Korea. PhD Dissertation. Seoul 
National University, Seoul, Korea.

Cleve-Euler A. 1953. Kongliga Svenska Vetenskaps-Akademiens Handligar, ser. 4, Vol. 4: Die Diatomeen von Schweden und Finnland. Part III. Monoraphideae, Biraphideae 1. Kongliga Svenska Vetenskaps-Akademiens, Stockholm, figs 484-970.

DeFelice DR, Lynts GW. 1978. Benthic marine diatom associations: Upper Florida Bay (Florida) and associated sounds. J Phycol 14: 25-33.

Drum RW, Webber E. 1966. Diatoms from a Massachusetts Salt Marsh. Bot Mar 9: 70-77.

Du G, Son M, Yun M, An S, Chung IK. 2009. Microphytobenthic biomass and species composition in intertidal flats of the Nakdong River estuary, Korea. Estuar Coast Shelf Sci 82: 663-672.

Hauboisa AG, Sylvestrec F, Guarinib JM, Richardb P, Blancharda GF. 2005. Spatio-temporal structure of the epipelic diatom assemblage from an intertidal mudflat in Marennes-Oléron Bay, France. Estuar Coast Shelf Sci 64: 385-394.

Hustedt F. 1939. Die Diatomeenflora des Küstengebietes der Nordsee vom Dollart bis zur Elbemündung. I. Die Diatomeenflora in den Sedimenten der unteren Ems sowie auf den Watten in der Leybucht, des Memmert und bei der Insel Juist. Abh Naturwiss Ver Bremen 31: 571-677.

Hustedt F. 1955. Marine littoral diatoms of Beaufort, North Carolina. Vol 6. Bulletin (Duke University Marine Station), Duke University Press, Durham, NC.

Hustedt F. 1961-1966. Die Kieselalgen. Deutschlands, Österreichs und der Schweiz unter Berücksichtigung der übrigen Länder Europas sowie der angrenzenden Meeresgebiete. Band VII, Teil 3. In: Kryptogamen-Flora von Deutschland, Österreich und der Schweiz (Rabenhorst L, ed). Akademische Verlagsgesellschaft $\mathrm{MBH}$, Leipzig, pp 161-348.

Hustedt F, Aleem AA. 1951. Littoral diatoms from the Salstone, near Plymouth. J Mar Biol Assoc UK 30: 177-196.

Kemp KD, Paddock TBB. 1989. Chambers within the valve of Diadema, gen. nov. Diatom Res 4: 39-45.

Kim CM, Yim YJ, Rim YD. 1972. The report for the IBP Vol 6. Studies on the primary production of the Phragmites longivalvis community in Korea. International Biological Programme Korean National Committee, Seoul. (in Korean)

Kim JH, Kim HS, Lee IK, Kim JW, Mun HT, Suh KH, Kim W, Kwon DH, Yoo SA, Suh YB, Kim YS. 1982. Studies on the estuarine ecosystem of the Nakdong River. Proc Coll Natur Sci Seoul national Univ 7: 121-163. (in Korean)

Kim SH, Rhew HS, Shin YH. 2007. The characterisitics and distribution of the surface sediment grain size of Na- kdong River deltaic barrier islands. J Korean Assoc Reg Geogr 13: 43-53. (in Korean)

Kosugi M. 1987. Limiting factors on the distribution of benthic diatoms in coastal regions. Salinity and substratum. Diatom 3: 21-31.

Krammer K, Lange-Bertalot H. 1986. Bacillariophyceae. Band 2/1, Teil 1. Naviculaceae. Susswasserflora von Mitteleuropa. Gustav Fisher Verlag, Jena.

Lange-Bertalot H. 2001. Diatoms of the European inland waters and comparable habitats. Vol 2. Diatoms of Europe. ARG Gantner Verlag KG, Ruggell.

Lange-Bertalot H, Metzeltin D. 1996. Indicators of oligotrophy - 800 taxa representative of three ecologically distinct lake types, Carbonate buffered - Oligodystrophic Weakly buffered soft water. Vol 2 (Lange-Bertalot H, ed). Iconographia Diatomologica-Annotated Diatom Micrographs- Ecology, Diversity, Taxonomy. Koeltz Scientific Books, Königstein, pp 2-390.

Mayama S, Kobayasi H. 1988. Morphological variations in Navicula atomus (Kütz.) Grun. In: Proceedings of the ninth international diatom symposium (Round EF, ed). Biopress, Bristol, pp 427-435.

Méléder V, Rincé Y, Barillé L, Gaudin P, Rosa P. 2007. Spatiotemporal changes in microphytobenthos assemblages in a macrotidal flat (Bourgneuf Bay, France). J Phycol 43: 1177-1190.

Mitbavkar S, Anil AC. 2002. Diatoms of the microphytobenthic community: population structure in a tropical intertidal sand flat. Mar Biol 140: 41-57.

Odum HT. 1956. Primary production in flowing waters. Limnol Oceanogr 1: 102-117.

Park J, Koh CH, Khim JS, Ohtsuka T, Witkowski A. 2012. Description of a new naviculoid diatom genus Moreneis gen. nov. (Bacillariophyta) from sand flats in Korea. J Phycol 48: 186-195.

Pomeroy LR. 1959. Algal productivity in salt marshes of Georgia. Limnol Oceanogr 4: 386-397.

Rao VNR, Lewin J. 1976. Benthic marine diatom flora of False Bay, San Juan Island, Washington. Syesis 9: 173-212.

Ribeiro L, Brotas V, Mascarell G, Coute A. 2003. Taxonomic survey of the microphytobenthic communities of two Tagus Estuary mudflats. Acta Oecol 24: 117-123.

Riznyk RZ. 1973. Interstitial diatoms from two tidal flats in Yaquina Estuary, Oregon, USA. Bot Mar 16: 113-138.

Round FE. 1960. The diatom flora of a salt marsh on the River Dee. New Phytol 59: 332-348.

Round FE. 1971. Benthic marine diatoms. Oceanogr Mar Biol Annu Rev 9: 83-139.

Sabbe K. 1993. Short-term fluctuations in benthic diatom numbers on an intertidal sandflat in the Westerschel- 
de estuary (Zeeland, The Netherlands). Hydrobiologia 269/270: 275-284.

Sabbe K, Vyverman W, Muylaert K. 1999. New and littleknown Fallacia species (Bacillariophyta) from brackish and marine intertidal sandy sediments in Northwest Europe and North America. Phycologia 38: 8-22.

Schmidt A. 1881. Atlas der Diatomaceen-kunde. Series II (Heft 17-18). Commissions-Verlag Von Ludwig, Aschersleben.

Schmidt A. 1936. Atlas der Diatomaceen-kunde. Series VIII (Heft 101-102). Commissions-Verlag Von Ludwig, Aschersleben.

Stidolph SR. 1985. Some benthic diatoms from Kapiti Island, near Cook Strait, New Zealand. Nova Hedwigia 41: 393-415.

Underwood GJC, Barnett M. 2006. What determines species composition in microphytobenthic biofilms? In: Functioning of microphytobenthos in estuaries (Kromkamp J, de Brouwer JFC, Blanchard GF, Forster RM, Créach V, eds). Royal Netherlands Academy of Arts and Sciences, Amsterdam, pp 123-140.

Underwood GJC, Phillips J, Saunders K. 1998. Distribution of estuarine benthic diatom species along salinity and nutrient gradients. Eur J Phycol 33: 173-183.

Witkowski A, Lange-Bertalot H, Kociolek JP, Kulikovskiy M, Bak M, Ruppel M. 2010. Diatom flora of San Francisco Bay and vicinity. II. Fogedia krammeri sp. nov. Polish Bot J 55: 49-53.

Witkowski A, Lange-Bertalot H, Metzeltin D. 2000. Diatom flora of marine coasts. Vol 1. In: Iconographia Diatomologica: Annotated Diatom Micrographs, (Lange-Bretalot H, ed), Vol 7. ARG Gantner Verlag KG, Rugell. 